\title{
Increase of Protein Synthesis by Uridine Supplement in Lectin-Stimulated \\ Peripheral Blood Lymphocytes and EB Virus-Transformed B Cell Line of Hereditary Orotic Aciduria Type I
}

\author{
Makoto Yazaki, Kazuki OkaJima, Mariko Suchi, \\ Hideko Morishita and Yoshiro Wada \\ Department of Pediatrics, Nagoya City University Medical \\ School, Nagoya 467
}

Yazaki, M., Okajima, K., Suchi, M., Morishita, H. and Wada, Y. Increase of Protein Synthesis by Uridine Supplement in Lectin-Stimulated Peripheral Blood Lymphocytes and EB Virus-Transformed B Cell Line of Hereditary Orotic Aciduria Type I. Tohoku J. exp. Med., 1987, 153 (3), 189-195_-A 2 month-old Japanese girl with hereditary orotic aciduria type I was treated with oral uridine supplement. The activities of orotate phosphoribosyltransferase (OPRT) and orotidine- 5 '-phosphate decarboxylase (ODC) in erythrocytes were 2.7 and $0.4 \%$, respectively, of those in the controls. Megaloblastic anemia, excessive urinary excretion of orotic acid, lymphopenia and decreased number of OKT3 positive lymphocytes on admission were corrected after the uridine supplement. Peripheral blood lymphocytes (PBL) were cultured for $24 \mathrm{hr}$ in RPMI 1640 medium with $10 \%$ heat-inactivated fetal calf serum and further stimulated with PHA-P, ConA or PWM in the presence of 10 to $1000 \mu \mathrm{M}$ uridine. EB virus-transformed $\mathrm{B}$ cell line (LCL) maintained with an optimal concentration of uridine was cultured for $48 \mathrm{hr}$ in uridine free medium and cultured for an additional $48 \mathrm{hr}$ with 1 to 1000 $\mu \mathrm{M}$ uridine. The incorporations of leucine in to PHA-, ConA- and PWMstimulated PBL and into LCL of the patient increased in the presence of uridine over $10 \mu \mathrm{M}$, although they did not increase in controls. These data suggest that low protein synthesis might correlate with an immune deficiency in hereditary orotic aciduria type I. $—$ uridine supplement; hereditary orotic aciduria type I ; immune deficiency

Hereditary orotic aciduria is a rare inborn error of pyrimidine metabolism associated with megaloblastic anemia, retarded growth and excessive urinary excretion of orotic acid. The enzyme defect involves either two sequential enzymes of de novo pyrimidine biosynthesis, orotate phosphoribosyltransferase (OPRT) and orotidine- 5 -phosphate decarboxylase (ODC) in type I form of the disease (Huguley et al. 1959; Becroft and Phillips 1965; Rogers et al. 1968; Becroft et al. 1969 ; Tubergen et al. 1969 ; Beardmore et al. 1972 ; Webster et al. 
1979 ; Girot et al. 1983 ; Morishita et al. 1986), or only ODC in type II form (Fox et al. 1969, 1973).

Oral uridine supplement usually improves clinical and hematological abnormalities. Correction of abnormal RNA and DNA synthesis by uridine supplement has been postulated, though not demonstrated. Three of twelve patients with this disease died from varicella or meningitis (Huguley et al. 1959; Fox et al. 1969 ; Girot et al. 1983). An immune deficiency has been suspected, although there are conflicting reports (Girot et al. 1983, 1984 ; Becroft et al. 1984).

In this report, we describe uridine supplement has normalized the number of OKT3 positive lymphocytes and has increased protein synthesis in lectinstimulated peripheral blood lymphocytes $(\mathrm{PBL})$ and $\mathrm{EB}$ virus-transformed $\mathrm{B}$ cell line (LCL) in vivo.

\section{Case Report}

A 2 month-old Japanese girl with severe anemia and ventricular septal defect was admitted to the Nagoya City University Hospital. Her parents were not related. Blood examination revealed erythrocytes of $1,910,000 / \mathrm{mm}^{3}$, hemoglobin $5.2 \mathrm{~g} / 100 \mathrm{ml}$, and hematocrit $15.7 \%$. Bone marrow examination revealed megaloblastic change with normal serum vitamin $\mathrm{B}_{12}$ and folic acid. Urinary excretion of orotic acid was $357 \mathrm{mg}$ per day. The activities of OPRT and ODC in erythrocytes were 2.7 and $0.4 \%$, respectively, of those in the controls. The activities of OPRT and ODC in LCL were 7.5 and $0.01 \%$, respectively, of those in the controls. Family study revealed parents were heterozygotes.

\section{Methods}

PBL were isolated by Ficoll-Isopaque gradient centrifugation. LCL was established using B95-8 derived EB virus. PBL were cultured for $24 \mathrm{hr}$ in RPMI 1640 medium (GIBCO, Grand Island, NY, USA) supplemented with 10\% heat-inactivated fetal calf serum (FCS) before the assay. $1.25 \times 10^{5} \mathrm{PBL}$ were further stimulated with phytohemagglutin-P (PHA-P) (Difco Laboratories, Detroit, MI, USA ; $15 \mu \mathrm{g} / \mathrm{ml}$ ) for 4 days, concanavalin A (ConA) (Miles Laboratories, Inc., Elkhart, IN, USA; $12.5 \mu \mathrm{g} / \mathrm{ml}$ ) for 5 days or pokeweed mitogen (PWM) (GIBCO ; diluted 1 to 2400 ) for 5 days in the presence of $10 \mu \mathrm{M}$ to $100 \mu \mathrm{M}$ uridine in flat-bottomed microtiter well containing $200 \mu \mathrm{l}$ RPMI 1640 with $10 \%$ heatinactivated FCS. LCL maintained with an optimal concentration of uridine was cultured for $48 \mathrm{hr}$ with uridine free medium, and $1 \times 10^{5} \mathrm{LCL}$ were cultured for an additional $48 \mathrm{hr}$ with 1 to $1000 \mu \mathrm{M}$ uridine in flat-bottomed microtiter well containing $200 \mu$ l RPMI 1640 with $10 \%$ heat-inactivated FCS. $0.5 \mu \mathrm{Ci}$ of $\left[\right.$ methyl $\left.^{3} \mathrm{H}\right]$ thymidine $(5 \mathrm{Ci} / \mathrm{mmole}$, Amersham Japan, Tokyo) or $0.5 \mu \mathrm{Ci}$ of L- $\left[4,5-{ }^{3} \mathrm{H}\right]$ leucine ( $\mathrm{Ci} / \mathrm{mmole}$, Amersham Japan) was added to each well $18 \mathrm{hr}$ before the end of the culture. The cultured cells were harvasted onto glass fiber filters with a multiple sample havester. The radioactivity in the cells was counted by a liquid scintillation counter. The concentration of uridine in plasma was determined by high-performance liquid chromatography (Mizuguchi 1983).

\section{RESUlts}

Immunological investigations were performed at 3 month-old before oral uridine supplement (Table 1). Levels of serum immunoglobulin were normal for her age. Total lymphocytes were $1,760 / \mathrm{mm}^{3}$ with low number of OKT3 positive 
TABLE 1. Immunological studies

\begin{tabular}{|c|c|c|c|c|c|}
\hline & \multicolumn{4}{|c|}{ Date } & \multirow{2}{*}{ Normal value } \\
\hline & $7 / 11 / 85$ & $12 / 21 / 85$ & $6 / 14 / 86$ & $10 / 18 / 86$ & \\
\hline Age at study & $3 \mathrm{~m}$ & $8 \mathrm{~m}$ & $1 \mathrm{y} 2 \mathrm{~m}$ & $1 \mathrm{y} 6 \mathrm{~m}$ & \\
\hline $\begin{array}{l}\text { Uridine intake } \\
\text { (mg/kg/day) }\end{array}$ & No & 150 & 150 & 300 & \\
\hline $\begin{array}{l}\text { Plasma uridine } \\
(\mu \mathrm{M})\end{array}$ & NT & NT & 17 & 30 & $\begin{array}{c}2.33 \pm 1.05^{*} \\
(\mathrm{M} \pm \text { s.D., } n=11)\end{array}$ \\
\hline \multicolumn{6}{|c|}{ Serum immunoglobulins } \\
\hline $\operatorname{IgG}(\mathrm{mg} / 100 \mathrm{ml})$ & 532 & 515 & NT & 796 & $270-1010$ \\
\hline $\operatorname{IgA}(\mathrm{mg} / 100 \mathrm{ml})$ & 36 & 50 & NT & 125 & $2-78$ \\
\hline $\operatorname{IgM}(\mathrm{mg} / 100 \mathrm{ml})$ & 144 & 109 & NT & 87 & 36-106 \\
\hline $\begin{array}{l}\text { Total leucocytes } \\
\left(\text { per } \mathrm{mm}^{3}\right)\end{array}$ & 4000 & 5500 & 7200 & 9500 & 5652-10992 \\
\hline $\begin{array}{l}\text { Total lymphocytes } \\
\quad\left(\text { per } \mathrm{mm}^{3}\right)\end{array}$ & 1760 & 3190 & 5328 & 3230 & $3433-7517$ \\
\hline \multicolumn{6}{|c|}{ Lymphocytes subsets (\%) } \\
\hline OKT 11 & NT & NT & NT & 72.8 & $68.0-81.8$ \\
\hline OKT 3 & 33.9 & 52.5 & NT & 70.2 & $54.4-73.0$ \\
\hline OKT 4 & 22.8 & 32.2 & NT & 35.3 & $32.3-48.7$ \\
\hline OKT 8 & 12.5 & 16.7 & NT & 25.2 & $18.8-32.6$ \\
\hline OKla 1 & 39.8 & 19.6 & NT & 16.1 & $10.3-21.9$ \\
\hline \multicolumn{6}{|c|}{ Blastgenesis $\left(\mathrm{cpm} \times 10^{-3}\right)$} \\
\hline PHA & NT & NT & 190 & NT & $58-187$ \\
\hline Con A & NT & NT & 160 & NT & $55-158$ \\
\hline PWM & NT & NT & 56 & NT & $20-66$ \\
\hline PHA skin test & NT & \pm & + & NT & \\
\hline
\end{tabular}

${ }^{*}$ Mizuguchi (1983).

NT, not tested; m, month; y, year.

lymphocytes and high number of OKIal positive lymphocytes as in the patients reported by Girot et al. (1983). Although megaloblastic anemia, excessive excretion of orotic acid, lymphopenia and decreased number of OKT3 positive lymphocytes were corrected at 8 month-old after 5 months uridine therapy (Fig. 1, Table 1), a skin test for PHA (10 $\mu \mathrm{g})$ was weak positive and challenge with dinitrochlorobenzene was negative. To study the effect of uridine on lymphocytes in vitro, we cultured lectin-stimulated PBL and LCL in the presence of 10 to $1000 \mu \mathrm{M}$ uridine at 1 year and 2 month-old after 11 months of uridine therapy. As shown in Tables 2 and 3, the incorporation of leucine into PHA-, ConA- and PWM- stimulated PBL and into LCL were increased in the patient by the addition of uridine, although that in control remained unchanged. The incorporation of thymidine in patient's LCL increased in the presence of $10 \mu \mathrm{M}$ uridine, although that in control's LCL did not (Table 3). 


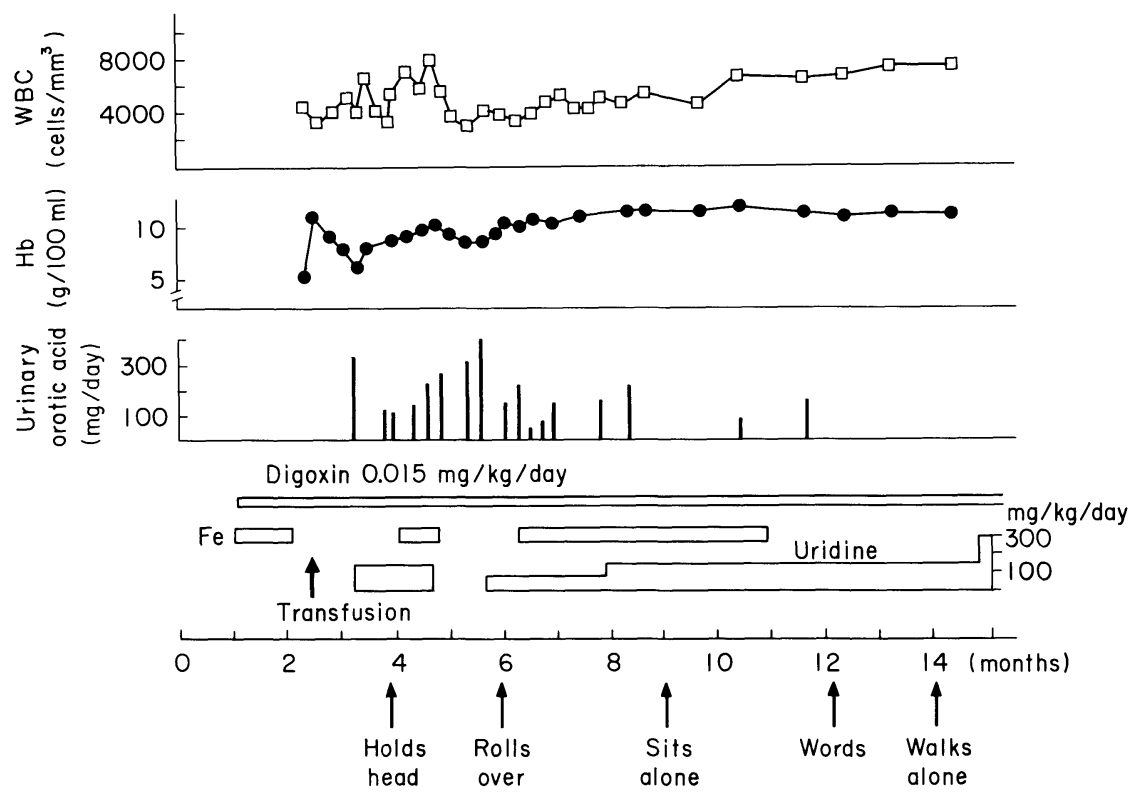

Fig. 1. Clinical course and treatment.

\section{Discussion}

Threre are conflicting reports whether or not hereditary orotic aciduria involves an immune deficiency. The cases whom Girot et al. (1983) reported had lymphopenia, low number of OKT3 positive lymphocytes, a decrease in T-cellmediated lymphocytolysis and an absence of PWM-induced plasma cell generation, although the case reported whom by Becroft et al. (1984) had no immunological abnormalities. Our case had lymphopenia and low number of OKT3 positive lymphocyte before the uridine therapy. We found uridine supplement increased the incorporation of leucine in lectin-stimulated PBL and LCL in vitro. These results suggest that uridine supplement might increase the important factors in immune response, then protect patients with this disease from severe infection. Since both the case of Huguley et al. (1959) and the case of Fox et al. (1969) had severe infection when they stopped nucleotide intake, continuous uridine supplement should be needed in order to maintain normal immune response.

Uridine supplement increased the incorporation of thymidine in patient's LCL. This result might be correlated with the megaloblastic change in erythroblasts. 


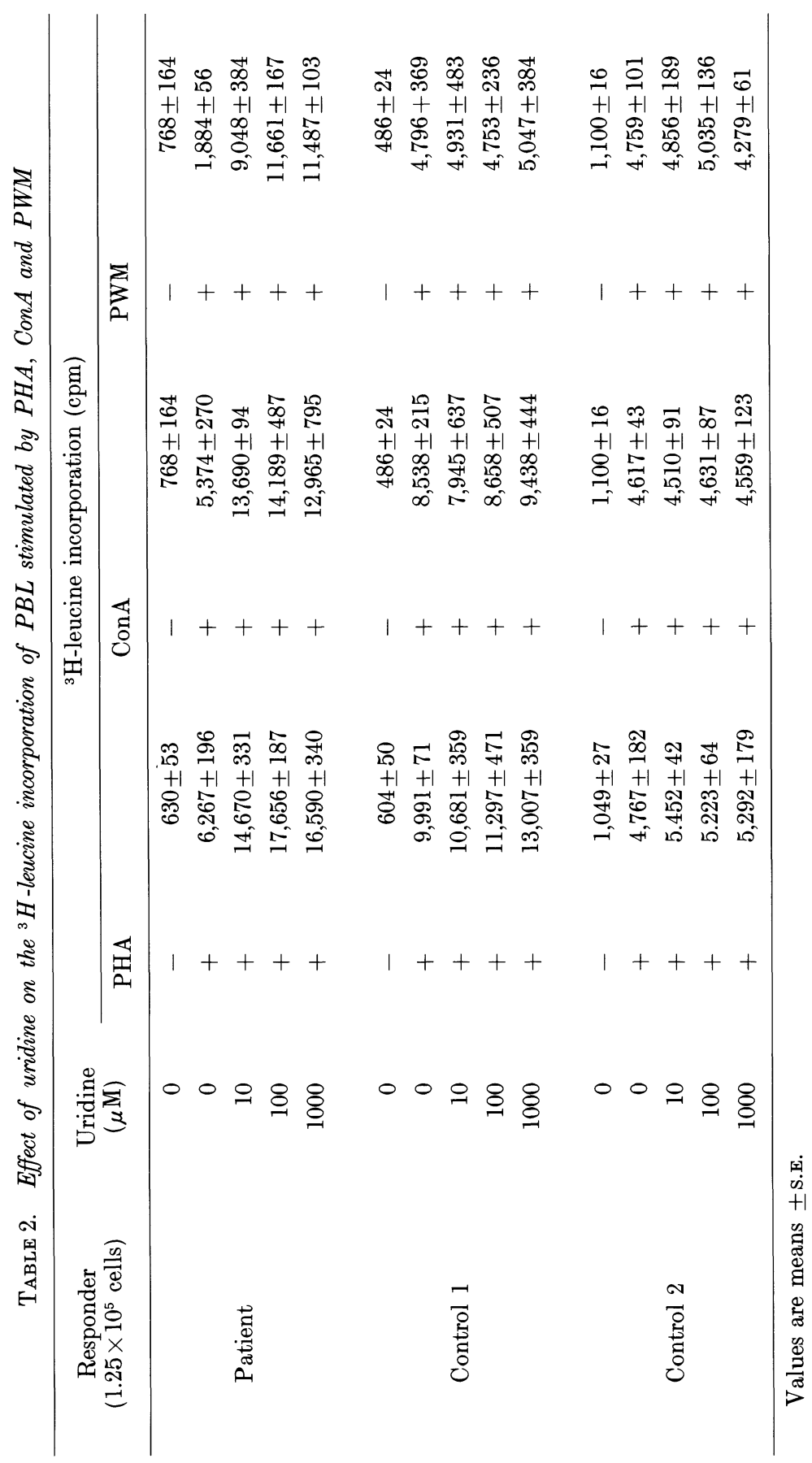


TABLE 3. Effect of uridine in EB virus-transformed $B$ cell line

\begin{tabular}{crcc}
\hline $\begin{array}{c}\text { Responder } \\
\left(1 \times 10^{5} \text { cell }\right)\end{array}$ & $\begin{array}{c}\text { Uridine } \\
(\mu \mathrm{M})\end{array}$ & $\begin{array}{c}{ }^{3} \mathrm{H} \text {-leucine } \\
\text { incorporation }(\mathrm{cpm})\end{array}$ & $\begin{array}{c}{ }^{3} \mathrm{H} \text {-thymidine } \\
\text { incorporation }(\mathrm{cpm})\end{array}$ \\
\hline & 0 & $5,751 \pm 183$ & $101,900 \pm 1,570$ \\
Patient's LCL & 1 & $6,287 \pm 208$ & $116,256 \pm 1,775$ \\
& 10 & $17,013 \pm 890$ & $215,016 \pm 5,179$ \\
& 100 & $17,856 \pm 190$ & $143,242 \pm 2,516$ \\
& 1000 & $16,523 \pm 755$ & $124,871 \pm 2,791$ \\
& 0 & $30,205 \pm 494$ & \\
Control's LCL & 1 & $29,688 \pm 672$ & $218,478 \pm 3,579$ \\
& 10 & $32,677 \pm 1,285$ & $220,093 \pm 2,689$ \\
& 100 & $28,596 \pm 221$ & $216,356 \pm 1,631$ \\
& 1000 & $30,603 \pm 2,331$ & $192,664 \pm 2,793$ \\
\end{tabular}

Values are means \pm s.E.

\section{References}

1) Beardmore, T.D., Cashman, J.S. \& Kelly, W.N. (1972) Mechanism of allopurinolmediated increase in enzyme activity in man. J. clin. Invest., 51, 1823-1832.

2) Becroft, D.M.O. \& Phillips, L.I. (1965) Hereditary orotic aciduria and megaloblastic anemia : A second case, with response to uridine. Brit. med. J., 1, 547-552.

3) Becroft, D.M.O., Phillips, L.I. \& Simmonds, A. (1969) Hereditary orotic aciduria : Long-term therapy with uridine and a trial of uracil. $J$. Pediat., 75, 885-891.

4) Becroft, D.M.O., Phillips, L.I., Webster, D.R. \& Wilson, J.D. (1984) Absence of immune deficiency in hereditary orotic aciduria. New Engl. J. Med., 310, 1333.

5) Fox, R.M., O'Sullivan, W.J. \& Firkin, B.G. (1969) Orotic aciduria: Differing enzyme patterns. Amer. J. Med., 47, 332-336.

6) Fox, R.M., Wood, M.H., Royse-Smith, D. \& O'Sullivan, W.J. (1973) Hereditary orotic aciduria: Type I and II. Amer. J. Med., 55, 791-798.

7) Girot, R., Hamet, M., Perignon, J., Guesnu, M., Cartier, P., Durandy, A. \& Grisgelli, C. (1983) Cellular immune deficiency in two siblings with hereditary orotic aciduria. New Engl. J. Med., 308, 700-704.

8) Girot, R., Durandy, A., Perignon, J. \& Gricelli, C. (1984) New Engl. J. Med., 310, 1334.

9) Huguley, C.M., Brain, J.A., Rivers, S.L. \& Scoggins, R.B. (1959) Refractory megaloblastic anemia associated with excretion of orotic acid. Blood, 14, 615-634.

10) Mizuguchi, K. (1983) Study of purine bases and nucleosides in various states of patients with inborn errors of purine metabolism. Nagoya med. J., 28, 83-96.

11) Morishita, H., Kokubo, M., Sumi, S., Suchi, M. \& Wada, Y. (1986) The first case of hereditary orotic aciduria in Japan. Nippon Shonika Gakkai Zasshi, 90, 2775-2778. (in Japanese with English abstract)

12) Rogers, L.E., Warford, L.R., Patterson, R.B. \& Porter, F.S. (1968) Hereditary orotic aciduria. I. A new case with family studies. Pediatrics, 42, 415-422.

13) Tubergen, D.G., Krooth, R.S. \& Heyn, R.M. (1969) Hereditary orotic aciduria with normal growth and development. Amer. J. Dis. Child., 118, 864-870.

14) Webster, D.R., Simmonds, H.A., Potter, C.F. \& Becroft, D.M.O. (1979) Purine and pyrimidine metabolism in hereditary orotic aciduria during a 15 year follow-up study. 
Advanc. exp. Med. Biol., 122B, 203-208. 